\title{
Performance of Sugarcane Farming Ratoon System in East Java Province
}

\author{
Arief Joko Saputro $^{1^{*}}$, Nuhfil Hanani ${ }^{2}$, Fahriyah ${ }^{2}$ \\ ${ }^{1}$ Postgraduate of Agriculture Economics Program, Faculty of Agriculture, Brawijaya University, Veteran \\ St. (65145), Malang, Indonesia \\ ${ }^{2}$ Departement of Socio-Economics, Faculty of Agriculture, Brawijaya University, Veteran St. (65145), \\ Malang, Indonesia
}

Received: 23 February 2021; Revised: 9 April 2021; Accepted: 9 July 2021

\begin{abstract}
The fulfillment of national sugar consumption needs cannot be achieved by domestic production. Increase sugar cane production to fulfill the availability of sugar in Indonesia, one of which in the central production area of East Java is still constrained by many sugarcane farmers who are doing ratoon system more than three times, so the productivity is low. This study aimed to analyze the performance sugarcane farming ratoon system in East Java by looking at technical efficiency and scale efficiency using the non-parametric approach of Data Envelopment Analysis (DEA). Sampling in this study used multistage random sampling in Kediri, Malang, and Mojokerto Districts. The average total technical efficiency (TE CRS) of farmers with 1-3 ratoons is 0.754 , the pure technical efficiency (TE VRS) is 0.817 , and the scale efficiency is 0.926 . The average TE CRS of farmers with 4-6 ratoons is 0.693, TE VRS is 0.814 , and the scale efficiency is 0.860. For farmers who do more than seven ratoons, an average TE CRS is 0.609 , TE VRS is 0.693 , and scale efficiency is 0.894 . The majority of sugarcane farmers at the research site have not been on an optimal business scale, namely in IRS conditions.
\end{abstract}

Keywords: performance; ratoon; sugarcane; technical; efficiency

\section{How to cite:}

Saputro, A. J., Hanani, N., \& Fahriyah. (2021). Performance of Sugarcane Farming Ratoon System in East Java Province. HABITAT, 32(2), 93-100. https://doi.org/10.21776/ub.habitat.2021.032.2.11

\section{Introduction}

Sugarcane is a plant planted in a country with a tropical climate that produced sugar and its side, used as a food and fuel source. Sugarcane in Indonesia is one of Indonesia's strategic plantation crops because it became a source of income for more than 995 thousand farmers (including labor) in 2019 (Directorate General of Plantation, 2019). According to the Ministry of Agriculture, sugarcane in Indonesia is produced in white crystal sugar (GKP) or hablur sugar to meet household and industrial needs.

The Average sugarcane production in Indonesia from 2014 to 2018 amounted to 23 million tons, with an average harvest area reaches 442 thousand hectares (FAOSTAT 2018). The area of national sugarcane harvest based on its business status, dominated by people's plantations, reached $57.7 \%$, state plantations by $15.6 \%$, and private plantations by $26.7 \%$. The decrease in the

${ }^{*}$ Correspondence Author.

E-mail: ariefjs12@gmail.com

Phone: +62-85722225275 area of sugarcane harvest in Indonesia from 2014 to 2018 is due to a decrease in people's plantation harvest by $6.91 \%$ (Ministry of Agriculture, 2020). The average growth of sugarcane production in Indonesia slowed by $2.39 \%$ from $2014-2018$, in line with the decline in the area of sugarcane harvest. The level of sugarcane productivity in Indonesia still fluctuates every year. Average sugarcane productivity was 53.45 tons per hectare, the highest in 2015 at 55.61 tons per hectare. The growth rate of sugarcane production in Indonesia is in line with the average productivity growth, which also decreased by $2.76 \%$.

The fulfillment of national sugar consumption needs cannot be achieved by domestic production, which averages only 2.2 million tons with an average consumption of 7 million tons in the range of 2016 to 2019. Therefore, to meet national sugar needs, the government increased the supply of sugar with a sugar import policy with an average volume of 4.4 million tons (OECD 2020). If national sugar cane production is still unable to meet the national sugar availability, import volumes are predicted to increase in line with Indonesia's increasing needs. 
Increase sugarcane production to fulfill the availability of sugar in Indonesia, one of which is in the central production area of East Java, in addition to constrained by the decline of the area of plantations of the people, and there are also many sugarcane farmers with a ratoon system who was ratooning more than three ratoons, thus becoming an obstacle in increasing sugarcane productivity (Fahriyah et al. 2018a). A ratoon planting system currently dominates sugarcane farming in Indonesia. This is because the new sugarcane plants (plant cane) required higher costs for ratoon unloading and seed procurement that reaches 10 tons per hectare (Balittas, 2019). Efforts in increasing production can be made one of them with the technical efficiency of sugarcane farmers, especially sugarcane farmers with ratoon system in the central production at East Java.

Some previous studies stated that, on average, sugarcane farmers' technical efficiency with ratoon system is lower than plant cane system; this is due to increased production required additional inputs (Yusuf et al. 2020). The technical efficiency of the sugarcane farming ratoon system is strongly influenced by fertilizer, namely NPK fertilizer. Also, the increasing number of ratooning can reduce farmer's revenue (Mulyanti 2019). The farming with ratoon system still has not reached efficiency because the seeds used are local seedlings that impacted low rendemen (Susilowati and Tinaprilla 2020).

This study analyzes how the sugarcane farming ratoon system's performance in East Java looks at technical efficiency and efficiency scale using a non-parametric approach of Data Envelopment Analysis (DEA). The efficiency approach of sugarcane farming with the DEA method shows the relative efficiency of each farmer. Farmers who use the most efficient inputs become a reference or peer for other farmers who had not efficiently use their inputs.

\section{Research Methods}

This research was conducted using the survey method of 148 respondent sugarcane farmers in East Java Province. Determination of respondents was carried out using a random sampling method. Kediri, Malang, and Mojokerto districts were selected as research samples considering that the three areas are sugarcane production central (based on area and productivity) in East Java Province. Farmers were chosen to be respondents of each region, in Kediri regency as many as 48 people, Malang regency as many as 50 people, and Mojokerto 50 people. The data collected is data on sugarcane farming in the $2019 / 2020$ growing season from September to October 2020.

\subsection{The Methods of Technical Efficiency of Sugarcane Farmer}

This study used the analysis method to measure the sugarcane farmers' ratoon system's performance in East Java Province using Data Envelopment Analysis (DEA). The DEA method of measuring efficiency does not measure the average value but measures the efficiency value of using production inputs. Input variables used include land area (ha), $\mathrm{N}$ fertilizer ( $\mathrm{kg}$ ), $\mathrm{P}$ fertilizer $(\mathrm{kg}), \mathrm{K}$ fertilizer $(\mathrm{kg})$, S fertilizer $(\mathrm{kg})$, pesticides (liters), and labors (HOK). Meanwhile, the output variable used in this research is sugarcane production (ton).

In this research, the assumption used in the DEA model is Variable Return to Scale (VRS) because farmers do not work on an optimal scale. Mathematically, the calculation of technical efficiency with VRS models is as follows (Coelli et al. 2005):

$$
\begin{gathered}
\operatorname{Min} \theta, \lambda \theta, \\
\text { st }-\mathrm{y} i+\mathrm{Y} \lambda \geq 0, \\
\theta x i-X \lambda \geq 0, \\
\mathrm{~N} 1^{\prime} \lambda=1 \\
\lambda \geq 0
\end{gathered}
$$

Where 1 is the score of Technical Efficiency (TE), Yi is the total production of the 1 st farmer, and xi is the Nx1 vector is the number of inputs used by the 1 st farmer, $Y$ is the $1 \mathrm{xM}$ vector for production, $\mathrm{X}$ is the NxM matric of the number of inputs used, $\lambda$ is the vector of $\mathrm{mx} 1$ and $\mathrm{s}$ is scalar. $\mathrm{N} 1{ }^{\prime} \lambda=1$ is a convexity that guarantees that efficiency is only a reference from DMU on the same scale (Asmara, 2017).

\subsection{The Method Efficiency of Scale}

The assumption of DEA VRS will bring up the value of Total Technical Efficiency (CRS) and Pure Technical Efficiency (TE VRS). The efficiency scale (SE) measure for each DMU is obtained from the TE CRS and TE VRS by decomposing the TE score obtained from the TE CRS into two components, the first is related to scale inefficiency, and the second is related to technical inefficiency. If there is a difference in TE scores in CRS and VRS in each DMU, DMU has scale inefficiencies. This concept can be described in the efficiency ratio as follows (Coelli et al. 2005):

$$
\mathrm{SE}=\mathrm{TE}_{\mathrm{CRS}} / \mathrm{TE} \mathrm{ERS}_{\mathrm{V} S}
$$




\section{Result and Discussion}

\subsection{The Conditions of Sugarcane Farming Ratoon System in East Java}

This research was conducted in three central sugarcane production in East Java Province, namely Kediri Regency, Malang Regency, and Mojokerto Regency. Based on data from the Central Statistics Agency (2020), Malang Regency is the area with the largest production and area of sugar cane in East Java Province, with an average production amount in 2015 to 2019 of an average of 238 thousand tons (in the form of hablur sugar) with an area of 42 thousand hectares (ha). Kediri regency is ranked second with an average production of 153 thousand tons (in the form of sugar hablur) with an average of 26 thousand hectares. The average amount of sugarcane production in Mojokerto regency of 53 thousand tons is 8.1 thousand hectares. Based on its productivity level, Mojokerto regency is the highest in East Java at an average of 6.5 tons per hectare, while Kediri Regency is 5.8 tons per hectare and Malang regency is 5.6 tons per hectare (in the form of hablur sugar).

According to Permentan No. 53, the Year 2015, the sugarcane ratoon system is a sugarcane plant that grows from previous plants' buds cut down. Sugarcane planting system requires maintenance (Rawat ratoon) to ensure productivity, and the rendemen is well maintained, among others, kepras activities to produce new shoots, purification, and root termination. The optimal sugarcane ratoon system plant population is between 72,000 and 75,000 stems per hectare (Balittas, 2019). Based on data in Table 1, sugarcane farmers' intermediate inputs in East Java Province to produce sugarcane production include land, fertilizer (N, P, K, S), pesticides, and labor.

Average sugarcane production in $2019 / 2020$ growing season is 94 tons with an average land area of 1.06 ha. The average workforce used in sugarcane farming is 556 working days (HOK) which shows that sugarcane cultivation is one of the cultivation activities that require a lot of labor-intensive. In addition to labor, fertilizer needs in sugarcane farming are relatively high. The average fertilizer used is $572,19 \mathrm{~kg}$. Previous research results also showed that the variables that most affect sugarcane. Previous research results also showed that the variables that most affect sugarcane production are labor, fertilizer, and pesticides (Dlamini et al. 2010). Sugarcane farmers in the Mojokerto regency were the highest on average used inputs. That is because the average land area is wider than the other two regencies. In cultivation, the sugarcane ratoon system, at the time of the 3rd ratoon (RC-3), causes a decrease in the productivity of the sugarcane plant. That is a cause of the soil starting to harden, and the number of weeds that have been formed into small diameter and potentially many sugarcane plants will die.

Table 1. Sugarcane Farm Output and Inputs Used

\begin{tabular}{|c|c|c|c|c|c|}
\hline \multicolumn{2}{|c|}{ Farm Inputs and Output } & \multirow{2}{*}{$\begin{array}{c}\text { Kediri } \\
76,74\end{array}$} & \multirow{2}{*}{$\begin{array}{c}\text { Mojokerto } \\
157.4\end{array}$} & \multirow{2}{*}{$\begin{array}{c}\text { Malang } \\
49,04\end{array}$} & \multirow{2}{*}{$\begin{array}{c}\text { Total } \\
94\end{array}$} \\
\hline \multirow{4}{*}{$\begin{array}{l}\text { Production } \\
\text { (ton) }\end{array}$} & Average & & & & \\
\hline & Minimum & 6,5 & 25 & 6 & 6 \\
\hline & Maximum & 200 & 480 & 220 & 480 \\
\hline & Stdev & 45,35 & 86,81 & 37,79 & 75,58 \\
\hline \multirow{4}{*}{$\begin{array}{l}\text { Land Areal } \\
\text { (ha) }\end{array}$} & Average & 0,83 & 1,80 & 0,56 & 1,06 \\
\hline & Minimum & 0,08 & $\begin{array}{l}1,00 \\
0,5\end{array}$ & 0,03 & 0,03 \\
\hline & Maximum & 2,14 & 5 & 2 & 5 \\
\hline & Stdev & 0,50 & 0,95 & 0,40 & 0,85 \\
\hline \multirow{4}{*}{$\begin{array}{l}\text { Fertilizer } \\
\quad(\mathrm{kg})\end{array}$} & Average & 437,97 & 788,97 & 497,42 & 572,19 \\
\hline & Minimum & 73 & 202,5 & 56,5 & 56,5 \\
\hline & Maximum & 1.220 & 1.800 & 2.260 & 2.260 \\
\hline & Stdev & 233,47 & 377,48 & 437,93 & 389,90 \\
\hline \multirow{4}{*}{$\begin{array}{l}\text { Pesticides } \\
\text { (Liter) }\end{array}$} & Average & 6,43 & 16,89 & 7,25 & 10,19 \\
\hline & Minimum & 0,5 & 2 & 1 & 0,5 \\
\hline & Maximum & 30 & 50 & 25 & 50 \\
\hline & Stdev & 6,13 & 11,58 & 5,83 & 9,45 \\
\hline \multirow{4}{*}{$\begin{array}{l}\text { Labor } \\
\text { (HOK) }\end{array}$} & Average & 310 & 1.093 & 249 & 556 \\
\hline & Minimum & 22 & 59 & 20 & 20 \\
\hline & Maximum & 875 & 7.724 & 983 & 7.724 \\
\hline & Stdev & 236 & $1.308,96$ & 197,90 & 867,75 \\
\hline
\end{tabular}


Table 2. The Distribution of Ratoon Frequency of Sugarcane Farmers

\begin{tabular}{|c|c|c|c|c|c|c|c|c|}
\hline \multirow{2}{*}{ Ratoon Frequency } & \multicolumn{2}{|c|}{ Kediri } & \multicolumn{2}{|c|}{ Mojokerto } & \multicolumn{2}{|c|}{ Malang } & \multicolumn{2}{|c|}{ Total } \\
\hline & Amount & $(\%)$ & Amount & $(\%)$ & Amount & $(\%)$ & Amount & $(\%)$ \\
\hline $1-3$ & 28 & 58,33 & 38 & 76 & 11 & 22 & 77 & 52,03 \\
\hline $4-6$ & 16 & 33,33 & 11 & 22 & 6 & 12 & 33 & 22,30 \\
\hline$\geq 7$ & 4 & 8,33 & 1 & 2 & 33 & 66 & 38 & 25,68 \\
\hline Maximum & \multicolumn{2}{|c|}{13} & \multicolumn{2}{|l|}{10} & \multicolumn{2}{|l|}{37} & \multicolumn{2}{|c|}{37} \\
\hline Average & \multicolumn{2}{|c|}{3} & \multicolumn{2}{|l|}{3} & \multicolumn{2}{|l|}{12} & \multicolumn{2}{|c|}{6} \\
\hline Stdev & \multicolumn{2}{|c|}{2,71} & \multicolumn{2}{|c|}{1,79} & \multicolumn{2}{|c|}{9,51} & \multicolumn{2}{|c|}{7,28} \\
\hline
\end{tabular}

Therefore, the government made a dismantling ratoon program carried out on the 3rd ratoon crops (Balittas, 2015). In previous research on sugarcane farmers in East Java, farmers, in general, are reluctant to grow sugar cane from nurseries because the increase in the cost of farming is much higher than the increase in income, so farmers tend to ratooning until the production decreases to the limit that they cannot tolerate (Ariningsih 2016). The majority of sugarcane farmers in East Java were doing a ratoon plant 1-3 ratoons with a proportion of $52.03 \%$. That indicates that most farmers have done ratoon procedures following the recommendations set out. Farmers who were ratooning 4-6 ratoons with a proportion of $18.92 \%$, and farmers who were doing more than 7 ratoons with a proportion of $29.05 \%$. The average sugarcane farmers in Malang regency became the most ratooning in 12 ratoons, with the highest ratoon frequency is 37 ratoons.

Table 3. Distribution of Total Technical Efficiency (TE CRS)

\begin{tabular}{ccccccc}
\hline \multirow{2}{*}{$\begin{array}{c}\text { Technical Efficiency } \\
\text { Level }\end{array}$} & \multicolumn{2}{c}{$\mathbf{1 - 3}$ Ratoons } & \multicolumn{2}{c}{ 4-6 Ratoons } & \multicolumn{2}{c}{$\geq 7$ Ratoons } \\
\cline { 2 - 7 } & Farmers & \% & Farmers & \% & Farmers & \% \\
\hline$\leq 0,599$ & 12 & 15,58 & 8 & 24.24 & 25 & 65.79 \\
$0,600-0,799$ & 37 & 48,05 & 17 & 51.52 & 11 & 28.95 \\
$0,800-0,999$ & 20 & 25,97 & 3 & 9.09 & 1 & 2.63 \\
1 & 8 & 10,39 & 5 & 15.15 & 1 & 2.63 \\
Total & 77 & 100 & 33 & 100 & 38 & 100 \\
\hline Minimum & 0,477 & \multicolumn{2}{c}{0,359} & & 0,369 \\
\hline Average & 0,754 & 0,693 & & 0,609 \\
\hline
\end{tabular}

\subsection{Technical Efficiency of Sugarcane Ratoon System}

The results of estimation analysis and distribution of technical efficiency using DEA with VRS models will show the value of total technical efficiency (TE CRS), pure technical efficiency (TE VRS), and efficiency scale. Based on the results of the analysis shown in Table 3, the average value of TE CRS shows that the technical efficiency of sugarcane farmers who perform 1 to 3 ratoons is 0.754 . That shows that farmers with 1 to 3 ratoons, on average, still experience technical inefficiencies $24.6 \%$ (TE CRS). The average TE CRS of sugarcane farmers with 4 to ratoons is 0.693, which means that there is still a technical inefficiency of $30.7 \%$ on average. Farmers who were ratooning more than seven times showed an average TE CRS value is 0.609 means that, on average, still on technical inefficiencies at $39.1 \%$. Sugarcane farmers can reduce their inputs and improve the scale of their efforts to achieve fully efficient conditions (TE=1). The average value of TE CRS indicates that sugarcane farmers with 1 to 3 ratoons had the highest TE CRS value, and sugarcane farmers who were ratooning more than seven ratoons had the lowest TE CRS value. According to the previous research that the technical efficiency of sugarcane farming on average has not reached full efficiency, so it still has the potential to be improved (Ali and Jan 2017; Fahriyah et al. 2018b; Ambetsa et al. 2020; Sumarno et al. 2020). 
Table 4. Distribution of Pure Technical Efficiency (TE VRS) Based on Amount of Ratoon

\begin{tabular}{ccccccc}
\hline Technical Efficiency & \multicolumn{2}{c}{$\mathbf{1 - 3}$ Ratoons } & \multicolumn{2}{c}{ 4-6 Ratoons } & \multicolumn{2}{c}{$\geq$ 7 Ratoons } \\
\cline { 2 - 7 } Level & Farmers & \% & Farmers & \% & Farmers & \% \\
\hline$\leq 0,599$ & 5 & 6.49 & 3 & 9.09 & 14 & 36.84 \\
$0,600-0,799$ & 31 & 40.26 & 14 & 42.42 & 18 & 47.37 \\
$0,800-0,999$ & 26 & 33.77 & 8 & 24.24 & 2 & 5.26 \\
1 & 15 & 19.48 & 8 & 24.24 & 4 & 10.53 \\
Total & 77 & 100 & 33 & 100 & 38 & 100 \\
\hline Minimum & 0,528 & \multicolumn{2}{c}{0,453} & 0,477 \\
\hline Average & 0,817 & \multicolumn{2}{c}{0,805} & 0,685 \\
\hline
\end{tabular}

The analysis results in Table 4 show that the average value of pure technical efficiency (TE VRS) of sugarcane farmers who do 1 to 3 ratoons is 0.817 . It shows that the average sugarcane farmer who performs 1 to 3 ratoons can reduce the inputs up to $18.3 \%$ without reducing its production to improve technical efficiency. The average TE VRS value of sugarcane farmers with 4 to 6 ratoons is 0.805 , which mean they can reduce their input usage up to $19.5 \%$ without reducing their production to improve technical efficiency. Farmers who were ratooning more than 7 ratoons showed an average TE VRS value is 0.685 , meaning that farmers can reduce their input usage by up to $19.5 \%$ without reducing their production to improve technical efficiency. The average value of TE VRS also shows the same pattern as the average value of TE CRS. Sugarcane farmers with 1 to 3 ratoons had the highest TE VRS value, and sugarcane farmers who were ratooning more than 7 ratoons had the lowest TE VRS value.

Tabel 5. Comparison of Ratoon Frequency with TE CRS, TE VRS and Efficiency Scale

\begin{tabular}{ccccccc}
\hline \multirow{2}{*}{ Ratoon Frequency } & \multicolumn{2}{c}{ TE CRS } & \multicolumn{2}{c}{ TE VRS } & \multicolumn{2}{c}{ Efficiency Scale } \\
\cline { 2 - 7 } & Average & Stdev & Average & Stdev & Average & Stdev \\
\hline $1-3$ & 0,754 & 0,152 & 0,817 & 0,147 & 0,926 & 0,089 \\
$4-6$ & 0,699 & 0,176 & 0,805 & 0,164 & 0,874 & 0,144 \\
$\geq 7$ & 0,594 & 0,132 & 0,685 & 0,159 & 0,884 & 0,152 \\
\hline
\end{tabular}

Table 5 shows the average value of sugarcane farmers with 1 to 3 ratoons has a higher average value of TE CRS and TE VRS than farmers who were ratooning 4 to 6 ratoons and farmers who were ratooning more than seven ratoons. Farmers who were ratooning more than three ratoons, so the value of technical efficiency on average will decrease. Farmers with ratooning more than seven ratoons showed the lowest average value of technical efficiency. It is thought that the inputs needed to achieve a specific product with the increasing number of ratooning each year will make the use of inputs more and become more inefficient in additions more inputs used, more ratooning each year cause lower rendemen obtained by farmers that have an impact on the decrease in farmer revenue. The average TE VRS value is lower than the efficiency scale, indicating that inputs cause more technical inefficiencies.

Data in Table 3 previously showed that the average amount of ratoons is more than 3 ratoons, with $48 \%$ of farmers doing more than recommended recommendations. It is suspected to do plant rejuvenation or replace plant for 3-4 years once it is considered that sugarcane farmers need a higher cost for planting than ratooning every year. Therefore, many sugarcane farmers prefer to do more ratoons than the recommendation to save on-farm costs incurred.

The practice of exceeding the recommended recommendation limit and impacting the quality of sugar cane produced is also suspected of causing a decrease in land quality on land used for cultivation and impact the decrease in farmers' productivity. The technical efficiency sugarcane farming ratoon system is still lower than the plant cane system (Widyawati 2020).

\subsection{Efficiency Scale Sugarcane Ratoon System Farm}

The estimated efficiency scale of the sugarcane farming ratoon system in Table 6 previously on average showed there is still a scale inefficiency. Scale inefficiency occurs because 
sugarcane farming does not work at the optimal scale, that name in conditions of Increasing Return to Scale (IRS) and or Decreasing Return to Scale (DRS). Sugarcane farming on IRS is a farm with too small business scale, while DRS is a farm with a large volume of scale business (Padilla-Fernandez and Nuthall 2012). ). Data in
Table 6 shows that farmers with 1 to 3 ratoons still on scale inefficiency $7.4 \%$, while farmers with 4 to 6 ratoons have more tremendous inefficiencies $12.6 \%$. Farmers who were ratooning more than seven ratoons also still on scale inefficiencies $11.6 \%$.

Tabel 6. The Distribution of Efficiency Scale Sugarcane Ratoon System

\begin{tabular}{ccccccc}
\hline Efficiency of & \multicolumn{2}{c}{$\mathbf{1 - 3}$ Ratoons } & \multicolumn{2}{c}{ 4-6 Ratoons } & \multicolumn{2}{c}{$\geq$ 7 Ratoons } \\
\cline { 2 - 7 } Scale & Farmers & \% & Farmers & \% & Farmers & \% \\
\hline$\leq 0,599$ & 0 & 0.00 & 3 & 9.09 & 4 & 10.53 \\
$0,600-0,799$ & 7 & 9.09 & 7 & 21.21 & 3 & 7.89 \\
$0,800-0,999$ & 58 & 75.32 & 18 & 54.55 & 30 & 78.95 \\
1 & 12 & 15.58 & 5 & 15.15 & 1 & 2.63 \\
Total & 77 & 100 & 33 & 100 & 38 & 100 \\
\hline Minimum & 0,600 & \multicolumn{6}{c}{0,488} \\
\hline Average & 0,926 & \multicolumn{3}{c}{0,874} & \multicolumn{3}{c}{0,443} \\
\hline
\end{tabular}

The data in Table 7 shows that sugarcane farming with various amounts of ratoons each shows a relatively similar pattern. The majority of sugarcane farmers have not been working on an optimal scale. Following the findings (Fahriyah et al. 2018b) that on the scale efficiency of sugarcane farming, more farms are operating under the optimal scale than on an optimal scale. In general, sugarcane farmers are on small-scale farming (Aminda et al. 2017). Farmers with 1-3 ratoons are 77 people, $15.58 \%$ farmers work on the optimal business scale (CRS), while farmers with $4-6$ ratoons are 28 people or $14.29 \%$ and farmers with more than 7 ratoons, only $6.98 \%$. Most farmers who do not operate on their optimal scale are increasing return to scale (IRS) conditions. Each farmer who was ratooning 1-3 ratoons is $77.92 \%$, farmers with $4-6$ ratoons are $67.86 \%$, and farmers with more than seven ratoons are $62.72 \%$. The IRS conditions indicate that business scale conditions are too small so that sugar cane farmers can still increase their business scale to achieve optimal business scale. The other small part is in the Decreasing Return to Scale (DRS) condition, as shown in Table 7.

Tabel 7. The Distribution of Efficiency Scale Sugarcane Ratoon System Based on Ratoon Frequency

\begin{tabular}{ccccccc}
\hline Efficiency of & \multicolumn{2}{c}{$\mathbf{1 - 3}$ Ratoons } & \multicolumn{2}{c}{ 4-6 Ratoons } & \multicolumn{2}{c}{$\geq$ 7 Ratoons } \\
\cline { 2 - 7 } Scale & Farmers & $\mathbf{\%}$ & Farmers & Farmers & \% & Farmers \\
\hline CRS & 12 & 15.58 & 4 & 14,29 & 3 & 6,98 \\
IRS & 60 & 77.92 & 19 & 67,86 & 27 & 62,72 \\
DRS & 5 & 6.49 & 5 & 17,86 & 13 & 30,23 \\
\hline Total & 77 & 100 & 28 & 100 & 43 & 100 \\
\hline
\end{tabular}

\section{Conclusion}

The average total technical efficiency (TE CRS) of farmers with 1-3 ratoons is 0.754 , the pure technical efficiency (TE VRS) 0.817 , and the efficiency of scale 0.926 . The average TE CRS of farmers with 4 to 6 ratoons is 0.693 , TE VRS 0.814 , and the efficiency of scale 0.860 . Farmers with more than seven ratoons, the average value of TE CRS 0.609, TE VRS 0.693, and efficiency of scale 0.894 . The majority of sugarcane farmers' ratoon system in East Java Province has not been in the optimal business scale to increase the return to scale (IRS) condition. That means that sugar cane farmers can still increase their business scale to achieve the optimal business of scale (CRS).

Efforts to achieve full efficient conditions technically, sugarcane farmers can improve input needs, especially fertilizer input under the recommendations dose, on time, and target. Also, sugarcane farming is one of the farming activities that involve much labor. The mechanization can save labor usage from cost and time. Farmers can regulate the amount of ratoon and dismantle sugarcane crops to rejuvenate crops. According to 
recommendations or a maximum of every 4-5 years or third ratoon, which is coupled with superior varieties to improve the quality of sugar cane produced. Besides, it is necessary to introduce seedlings of superior varieties through counseling and mentoring because the conditions in the field show that many sugarcane farmer's ratoon systems reject switching using superior varieties.

\section{References}

Ali A, Jan AU. 2017. Analysis of Technical Efficiency of Sugarcane Crop in Khyber Pakhtunkhwa: A Stochastic Frontier Approach. Sarhad J Agric. 33(1):69-79. doi:10.17582/journal.sja/2017.33.1.69.79.

Ambetsa LF, Mwangi SC, Ndirangu SN. 2020. Technical efficiency and its determinants in sugarcane production among smallholder sugarcane farmers in Malava sub-county, Kenya. African J Agric Res. 15(3):351-360. doi:10.5897/ajar2020.14703.

Aminda FR, Sinaga BM, Fariyanti A. 2017. Dampak Faktor Eksternal Terhadap Kesejahteraan Rumah Tangga Petani Tebu Keprasan di Jawa Tengah. J Agro Ekon. 35(2):127-150.

Ariningsih E. 2016. Dampak Keanggotaan Koperasi terhadap Pendapatan Petani Tebu di Provinsi Jawa Timur. J Agro Ekon. 32(2): 147. doi:10.21082/jae.v32n2.2014.147-165.

Asmara, Rosihan. 2017. Efisiensi Produksi: Pendekatan Stokastik Frontier dan Data Envelopment Analysis (DEA). Jurusan Sosial Ekonomi Pertanian, Fakultas Pertanian, Universitas Brawijaya. Malang.

Badan Pusat Statistik (BPS). 2020. Statistik Provinsi Jawa Timur dalam Angka Tahun 2016-2020. Badan Pusat Statistik Provinsi Jawa Timur. Surabaya.

Balai Penelitian Tanaman Pemanis dan Serat (Balittas). 2015. Leaflet Rawat Ratoon Tebu di Lahan Kering [internet]. Kementerian Pertanian. [Update 20 Februari 2018; disitasi 7 Februari 2021]. Available on: http://balittas.litbang.pertanian.go.id/.

Balai Penelitian Tanaman Pemanis dan Serat (Balittas). 2019. Rawat Ratoon Tebu [internet]. Kementerian Pertanian. [Update 29 Maret 2019; disitasi 7 Februari 2021]. Available on: http://balittas.litbang .pertanian.go.id/

Coelli TJ, Prasada Rao DS, O'Donnell CJ, Battese GE. 2005. An introduction to efficiency and productivity analysis.

Dlamini S, Rugambisa JI, Masuku MB, Belete A. 2010. Technical efficiency of the small scale sugarcane farmers in Swaziland: A case study of Vuvulane and Big bend farmers. African J Agric Res. 5(9):935940. doi:10.5897/AJAR09.368.

Fahriyah F, Hanani N, Koestiono D, Syafrial S. 2018a. Analisis Efisiensi Teknis Usahatani Tebu Lahan Sawah dan Lahan Kering dengan Pendekatan Data Envelopment Analysis (DEA). J Ekon Pertan dan Agribisnis. 2(1):77-82. doi:10.21776/ub jepa.2018.002.01.8.

Fahriyah F, Hanani N, Koestiono D, Syafrial S. 2018b. Technical Efficiency and Scale Efficiency of Sugarcane Production. Russ J Agric Socio-Economic Sci. 5(May):188194. https://cyberleninka.ru/article/n/technicalefficiency-and-scale-efficiency-ofsugarcane-production.

FAOSTAT. 2018. Indonesia Sugarcane Statistical Databases [internet]. FAO Statistics. [Update 22 Desember 2020; disitasi 31 Desember 2020] Tersedia dari http://www.FAO.org/.

Mulyanti DR. 2019. Technical efficiency and Income Level of Sugarcane Farming in Pati Regency. J Agro Ekon. 37(2):95-112.

Organization for Economic of Co-operation and Development (OECD). 2020. OECD-FAO Agricutural Outlook 2018-2027: sugar [internet]. FAO. [Update Juli 2018; disitasi 31 Desember 20210]. Available on: http:/stats.oecd.org/

Padilla-Fernandez MD, Nuthall PL. 2012. Farm size and its effect on the productive efficiency of sugar cane farms in central Negros, the Philippines. J Int Soc Southeast Asian Agric Sci. 18(1):49-61.

Sumarno J, Anasiru RH, Retnawati E. 2020. Efisiensi Usahatani Tebu di Provinsi Gorontalo. J Penelit Tanam Ind. 26(1):11. 
doi:10.21082/jlittri.v26n1.2020.11-22.

Susilowati SH, Tinaprilla N. 2020. Analisis Efisiensi Usaha Tani Tebu Di Jawa Timur. J Penelit Tanam Ind. 18(4):162. doi:10.21082/jlittri.v18n4.2012.162-172.

The Ministry Agriculture of Indonesia. 2019. Outlook Komoditas Perkebunan Tanaman Tebu Tahun 2019. Kementerian Pertanian. Jakarta

Widyawati W. 2020. Technical Efficiency Analysis of Sugar Cane Production in East Java. Habitat. 31(2):95-101. doi:10.21776/ub.habitat.2020.031.2.11.

Yusuf MT, Jamhari J, Irham I. 2020. Technical Efficiency of State-Owned Sugarcane Production in East Java. Agro Ekon. 31(1). doi:10.22146/ae.50004. 